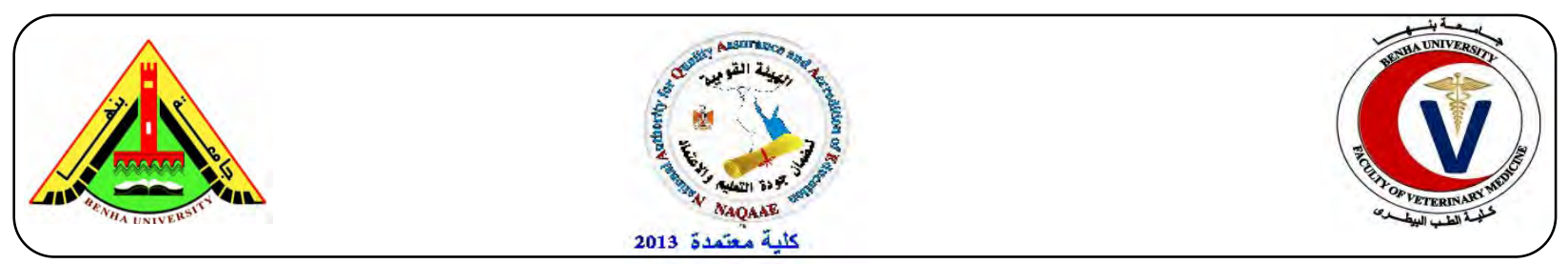

\title{
Impact of industrial wastewater on water and fish quality of Nile River in Kafr El-Zayat, Egypt
}

\author{
Ahmed E. Alawy ${ }^{1}$, Wael F. El-Tras ${ }^{1}$, Dalia F. khater ${ }^{2}$, and Hala R. El Raiy ${ }^{1}$ \\ ${ }^{1}$ Hygiene and Preventive Medicine Dept., Fac. Vet. Med., Kafr elsheikh University \\ ${ }^{2}$ Food Hygiene Dept., Tanta lab., Animal Health Research Institute
}

\section{A B S T R A C T}

In Egypt, Rosetta branch of the Nile River is impacted by several industrial effluents at Kafr El-Zayat City, which potentially affect and deteriorate its quality. To study the impact of these effluents on aquatic environment of the Rosetta branch, a total of 108 water samples and 36 fish samples were collected during the spring and autumn 2010 from 9 different regions along the branch at Kafr ElZayat industrial area. Chemical analyses of water samples showed seasonal variation of $\mathrm{pH}, \mathrm{Pb}, \mathrm{Cd}$, and $\mathrm{NH} 3$ values. $\mathrm{Cu}$ concentrations in the water were below the maximum permissible limit, however, $\mathrm{Pb}, \mathrm{Cd}, \mathrm{Hg}, \mathrm{P}, \mathrm{NH} 3$, and $\mathrm{S}$ exceeded the permissible limit. The distribution of these parameters at the area under investigations are strongly affected by the industrial effluents produced from El-Mobidat, El-Malyia and Salt and Soda companies which directly discharge industrial effluents at this area without any treatment. The presence of high levels of $\mathrm{Pb}, \mathrm{Hg}, \mathrm{NH} 3$, and $\mathrm{S}$ in the fish muscles were in relation to water pollution in the studied area. The bacteriological analyses showed that TBC ranged from $1.9 \times 10^{3}$ to $5 \times 10^{5} \mathrm{cfu} / \mathrm{ml}$ for water and from $3 \times 10^{5}$ to $5 \times 10^{5} \mathrm{cfu} / \mathrm{g}$ for fish flesh. Importantly, the water and fish samples tested were positive for Salmonella and negative for E. Coli. In conclusion, the results demonstrate that the Nile River at Kafr El- Zayat industrial area is heavily polluted and consequently harmful effects to the aquatic environment and to the quality of the water are established. So, treatment and safe disposal of different industrial wastes is recommended.

Keywords: Water quality, Fish quality, Pollutants, River Nile, Kafr El-Zayat

\section{INTRODUCTION}

$\mathbf{T}$ he Nile River considers the longest river in the world. The main River Nile when reaches to the Delta is divided into two branches Rosetta and Damiata branches. The Rosetta branch water serves for a wide range of functions including agricultural, industrial and domestic water supply, fisheries and recreation. However, unfortunately the Rosetta Branch is impacted by several industrial companies at Kafr El-Zayat City. These industrial outfalls are El-Mobidat (Pesticides and chemical company, KZ, produced more than 40 kinds of chemical products, including agricultural pesticides and household pesticides in addition to fertilizer); El-Malyia (pesticide production company, IFIC, produced superphosphate, different types of sulphuric acid, sodium fluosilicate, ferrous sulphates); and Salt and Soda (produced oil, soap, wax, animal fodder, liquid and solid sodium silicates) companies which are discharging directly at the east bank of the branch. There were several studies concerned with the environmental status of the Nile River through the analysis of water and fish (Massoud and Mahdi, 1985; Elewa, 1991; Gomaa, 1995 and Abdo, 2002). However, information about the quality of other components of the eco-system is lacking. The continual anthropogenic input of 
heavy metals in aquatic habitats constitutes a potential threat to ecosystem by direct toxication of these metals to aquatic organisms (Nuzzi, 1972; Bella and Mccauley 1972). Moreover, heavy metals and other trace elements have been considered as dangerous substances causing serious health progressive irreversible accumulation in humans as a result of a repeated consumption of small amounts of these elements (Wheaton and Lawson, 1985). On the other hand, the fish acts as a vehicle for many microorganisms from its natural contaminated aquatic environment, sewage, soil and harvesting areas (Shewan, 1971 and National Academy of Science, 1985). The bacterial load of fish is a reflection of the water status in which they were caught and fish can acquire pathogenic microorganisms from the natural aquatic environment (National Academy of Science, 1985; Goosney et al., 2001). Therefore, current study was conducted to assess the pollution and contamination of Rosetta branch of Nile River at Kafr El-Zayat industrial area during spring and autumn 2010 to assess the risk of water pollution with chemicals and pathogenic microorganisms, which affect the humans and veterinary public health.

\section{MATERIALS AND METHODS}

\subsection{Sample collection}

The water and fish samples were collected during the spring and autumn 2010 from 9 different regions of Rosetta branch of Nile River at Kafr El-Zayat industrial area as follows:

- Point 1: about 2 kilo meters north the drainage of Salt and Soda Company.

- Point 2: at the drainage of Salt and Soda Company.

- Point 3: at the drainage of El-Malyia Company.

- Point 4: at the drainage of El-Mobidat Company.
- Point 5: at the other side of Nile River, opposite the drainage of El-Malyia Company.

- Point 6: at the other side of Nile River, opposite the drainage of Salt and Soda Company.

- Point 7: beside animal carcass.

- Point 8: at the other side of Nile River, opposite the drainage of El-Mobidat Company.

- Point 9: about 2 kilo meters south the drainage of El-Mobidat Company.

The water samples were obtained from all 9 points during spring and autumn of 2010; 3 samples were collected from each point in clean plastic bottles for chemical analysis, and another 3 samples (a total of 108 water samples) were also collected in sterilized glass bottle for bacteriological analysis (Rabeh, 2007). The fish samples were obtained only from points 1, 3 and 9 during the same periods; similarly 6 samples were collected from each point (a total of 36 fish samples), 3 for chemical analysis, and another 3 samples for bacteriological analysis (Ragab, 2001).

\subsection{Determination of $p H$}

$\mathrm{pH}$ values of water was measured by using chromatography HPLC digital $\mathrm{pH}$ meter (Ragab, 2001).

\subsection{Chemical Analysis:}

Ammonia (APHA, 1998), Phosphorus (Ragab, 2001), Sulpher (Grondelle et. al., 1977) and heavy metals (APHA, 1998) of Lead, Mercury, Copper and Cadmium were determined in the examined samples.

\subsection{Bacteriological examination}

All samples were analyzed for total aerobic count, isolation and identification of Salmonella and Escherichia coli according to APHA (1998), ICMSF (1978) and Mari'a et al., (2007) respectively.

\section{RESULTS}

\subsection{Chemical Analysis of water}


The mean concentrations of the tested parameters in the water of the Nile River at Kafr EL-Zayat are presented in Table 1, 2 \& 3. Metal concentrations followed an abundance of $\mathrm{Hg}>\mathrm{Pb}>\mathrm{Cu}>\mathrm{Cd}$., in spring and they were in the following order: $\mathrm{Hg}>\mathrm{Cu}>\mathrm{Pb}>\mathrm{Cd}$ in autumn. Seasonal variation of $\mathrm{pH} \mathrm{Pb}, \mathrm{Cd}$, and $\mathrm{NH} 3$ water values were observed.

\subsection{Bacteriological analysis of water}

TBCs of the analyzed water samples ranged from $6 \times 10^{3}$ to $5 \times 10^{5} \mathrm{cfu} / \mathrm{ml}$ and from $1.9 \times 10^{3}$ to $3.7 \times 10^{5} \mathrm{cfu} / \mathrm{ml}$ in spring and autumn, respectively (Table 4). Salmonella were identified in points 1, 5, 6, 7, 8, 9; meanwhile Escherichia coli were not detected in any water sample.

\subsection{Chemical Analysis of fish muscles}

Table 5 shows the concentrations of the tested parameters in fish flesh. The accumulation of the measured heavy metals increases in the following order, $\mathrm{Cd}$ $<\mathrm{Cu}<\mathrm{Pb}<\mathrm{Hg}$.

\subsection{Bacteriological analysis of fish muscles}

TBCs of the analyzed fish muscles ranged from $4 \times 10^{5}$ to $5 \times 10^{5} \mathrm{cfu} / \mathrm{g}$ in spring and from $3 \times 10^{5}$ to $5 \times 10^{5} \mathrm{cfu} / \mathrm{g}$ in autumn (Table 5). The entire fish samples tested were positive for Salmonella and negative for E. Coli.

Table (1): $\mathrm{pH}$, Copper, and Lead values $(\mathrm{N}=3)$ in water of Nile River at Kafr EL-Zayat industrial area during spring and autumn 2010. (Mean \pm SE).

\begin{tabular}{ccccccc}
\hline Season & \multicolumn{3}{c}{ Spring } & \multicolumn{3}{c}{ Autumn } \\
Location & $\mathrm{pH}$ & $\mathrm{Cu}$ & $\mathrm{Pb}$ & $\mathrm{pH}$ & $\mathrm{Cu}$ & $\mathrm{Pb}$ \\
\hline Point 1 & $7.11 \pm 0.038$ & $0.30 \pm 0.032$ & $0.51 \pm 0.018$ & $7.05 \pm 0.029$ & $0.07 \pm 0.005$ & $0.02 \pm 0.005$ \\
Point 2 & $7.05 \pm 0.0284$ & $0.19 \pm 0.015$ & $0.34 \pm 0.012$ & $7.16 \pm 0.029$ & $0.04 \pm 0.008$ & $0.03 \pm 0.005$ \\
Point 3 & $7.74 \pm 0.055$ & $0.27 \pm 0.017$ & $0.34 \pm 0.009$ & $7.14 \pm 0.021$ & $0.05 \pm 0.014$ & $0.03 \pm 0.005$ \\
Point 4 & $7.3 \pm 0.088$ & $0.27 \pm 0.024$ & $0.34 \pm 0.009$ & $7.15 \pm 0.023$ & $0.05 \pm 0.014$ & $0.03 \pm 0.006$ \\
Point 5 & $7.6 \pm 0.052$ & $0.27 \pm 0.026$ & $0.55 \pm 0.017$ & $8.01 \pm 0.029$ & $0.06 \pm 0.015$ & $0.04 \pm 0.005$ \\
Point 6 & $7.2 \pm 0.120$ & $0.25 \pm 0.020$ & $0.55 \pm 0.017$ & $7.30 \pm 0.014$ & $0.06 \pm 0.017$ & $0.04 \pm 0.012$ \\
Point 7 & $6.5 \pm 0.088$ & $0.27 \pm 0.017$ & $0.37 \pm 0.005$ & $6.7 \pm 0.080$ & $0.06 \pm 0.018$ & $0.03 \pm 0.005$ \\
Point 8 & $6.5 \pm 0.057$ & $0.29 \pm 0.014$ & $0.18 \pm 0.002$ & $7.16 \pm 0.031$ & $0.06 \pm 0.018$ & $0.02 \pm 0.005$ \\
Point 9 & $7.4 \pm 0.059$ & $0.30 \pm 0.008$ & $0.18 \pm 0.003$ & $6.76 \pm 0.059$ & $0.07 \pm 0.017$ & $0.03 \pm 0.008$ \\
\hline
\end{tabular}

Table (2): Concentrations of Cadmium, Mercury, and Phosphorus $(N=3)$ in water of Nile River at Kafr EL-Zayat industrial area during spring and autumn 2010. (Mean \pm SE).

\begin{tabular}{ccccccc}
\hline Season & \multicolumn{4}{c}{ Spring } & \multicolumn{3}{c}{ Autumn } \\
Location & $\mathrm{Cd}$ & $\mathrm{Hg}$ & $\mathrm{P}$ & $\mathrm{Cd}$ & $\mathrm{Hg}$ & $\mathrm{P}$ \\
\hline Point 1 & $\mathrm{ND}$ & $0.71 \pm 0.02$ & $0.18 \pm 0.010$ & $0.05 \pm 0.008$ & $0.43 \pm 0.028$ & $0.40 \pm 0.002$ \\
Point 2 & $\mathrm{ND}$ & $0.78 \pm 0.03$ & $0.07 \pm 0.004$ & $0.02 \pm 0.005$ & $0.44 \pm 0.02$ & $0.31 \pm 0.006$ \\
Point 3 & $\mathrm{ND}$ & $0.61 \pm 0.017$ & $0.027 \pm 0.001$ & $0.02 \pm 0.005$ & $0.43 \pm 0.01$ & $0.32 \pm 0.012$ \\
Point 4 & ND & $0.54 \pm 0.05$ & $0.02+0.005$ & $0.02 \pm 0.005$ & $0.60 \pm 0.02$ & $0.31 \pm 0.007$ \\
Point 5 & ND & $0.60 \pm 0.02$ & $0.017 \pm 0.002$ & $0.03 \pm 0.005$ & $0.38 \pm 0.01$ & $0.21 \pm 0.009$ \\
Point 6 & ND & $0.64 \pm 0.017$ & $0.024 \pm 0.001$ & $0.03 \pm 0.005$ & $0.43 \pm 0.02$ & $0.27 \pm 0.005$ \\
Point 7 & ND & $0.29 \pm 0.037$ & $0.03 \pm 0.0005$ & $0.02 \pm 0.005$ & $0.43 \pm 0.02$ & $0.31 \pm 0.006$ \\
Point 8 & ND & $0.57 \pm 0.05$ & $0.525 \pm 0.012$ & $0.01 \pm 0.003$ & $0.36 \pm 0.01$ & $0.26 \pm 0.004$ \\
Point 9 & ND & $0.76 \pm 0.05$ & $0.029 \pm 0.004$ & $0.02 \pm 0.005$ & $0.39 \pm 0.014$ & $0.31 \pm 0.004$ \\
\hline
\end{tabular}

ND: Not Detected 
Table (3): Concentrations of Ammonia and Sulpher $(\mathrm{N}=3)$ in water of Nile River at Kafr ELZayat industrial area during spring and autumn 2010. (Mean \pm SE).

\begin{tabular}{ccccc}
\hline Season & \multicolumn{2}{c}{ Spring } & \multicolumn{2}{c}{ Autumn } \\
Location & $\mathrm{NH3}$ & $\mathrm{S}$ & $\mathrm{NH} 3$ & $\mathrm{~S}$ \\
\hline Point 1 & $0.32 \pm 0.024$ & $14.4 \pm 0.28$ & $3.2 \pm 0.12$ & $11.38 \pm 0.42$ \\
Point 2 & $0.32 \pm 0.008$ & $16.06 \pm 0.46$ & $3.4 \pm 0.14$ & $12.73 \pm 0.79$ \\
Point 3 & $0.37 \pm 0.02$ & $19.28 \pm 0.2$ & $7.2 \pm 0.24$ & $14.66 \pm 0.29$ \\
Point 4 & $0.04 \pm 0.005$ & $54.09 \pm 0.87$ & $3.7 \pm 0.05$ & $38.11 \pm 1.51$ \\
Point 5 & $0.04 \pm 0.008$ & $15.51 \pm 0.23$ & $2.9 \pm 0.008$ & $12.36 \pm 0.43$ \\
Point 6 & $0.3 \pm 0.01$ & $6.78 \pm 0.03$ & $4.3 \pm 0.21$ & $5.4 \pm 0.21$ \\
Point 7 & $0.04 \pm 0.005$ & $13.64 \pm 0.16$ & $5.2 \pm 0.2$ & $12.4 \pm 0.43$ \\
Point 8 & $0.07 \pm 0.012$ & $29.16 \pm 0.92$ & $4.1 \pm 0.12$ & $18.66 \pm 0.66$ \\
Point 9 & $0.06 \pm 0.008$ & $14.6 \pm 0.18$ & $5.1 \pm 0.21$ & $10.99 \pm 0.26$ \\
\hline
\end{tabular}

Table (4): Bacteriological analysis $(\mathrm{N}=3)$ of water of Nile River at Kafr EL-Zayat industrial area during spring and autumn 2010. (Mean \pm SE).

\begin{tabular}{ccccccc}
\hline Season & \multicolumn{2}{c}{ Spring } & \multicolumn{3}{c}{ Autumn } \\
Location & TBCs & Salmonella & E. Coli & TBCs & Salmonella & E. Coli \\
\hline Point 1 & $1.6 \times 10^{4} \pm 5.7 \times 10^{2}$ & $+\mathrm{ve}$ & $-\mathrm{ve}$ & $3.7 \times 10^{5} \pm 6.5 \times 10^{4}$ & $+\mathrm{ve}$ & $-\mathrm{ve}$ \\
Point 2 & $5 \times 10^{5} \pm 1.1 \times 10^{5}$ & $-\mathrm{ve}$ & $-\mathrm{ve}$ & $2.1 \times 10^{5} \pm 5.7 \times 10^{3}$ & $-\mathrm{ve}$ & $-\mathrm{ve}$ \\
Point 3 & $3.6 \times 10^{4} \pm 8 \times 10^{3}$ & $-\mathrm{ve}$ & $-\mathrm{ve}$ & $5.1 \times 10^{3} \pm 4 \times 10^{2}$ & $-\mathrm{ve}$ & $-\mathrm{ve}$ \\
Point 4 & $9 \times 10^{3} \pm 1.5 \times 10^{3}$ & $-\mathrm{ve}$ & $-\mathrm{ve}$ & $4 \times 10^{3} \pm 5.7 \times 10^{2}$ & $-\mathrm{ve}$ & $-\mathrm{ve}$ \\
Point 5 & $3 \times 10^{4} \pm 1.2 \times 10^{3}$ & $+\mathrm{ve}$ & $-\mathrm{ve}$ & $1.9 \times 10^{3} \pm 1.2 \times 10^{2}$ & $+\mathrm{ve}$ & $-\mathrm{ve}$ \\
Point 6 & $3 \times 10^{4} \pm 01.5 \times 10^{4}$ & $+\mathrm{ve}$ & $-\mathrm{ve}$ & $6 \times 10^{4} \pm 1.5 \times 10^{4}$ & $+\mathrm{ve}$ & $-\mathrm{ve}$ \\
Point 7 & $6 \times 10^{3} \pm 1 \times 10^{3}$ & $+\mathrm{ve}$ & $-\mathrm{ve}$ & $6 \times 10^{3} \pm 1.4 \times 10^{2}$ & $+\mathrm{ve}$ & $-\mathrm{ve}$ \\
Point 8 & $4.6 \times 10^{4} \pm 2.1 \times 10^{4}$ & $+\mathrm{ve}$ & $-\mathrm{ve}$ & $3.6 \times 10^{5} \pm 8 \times 10^{4}$ & $+\mathrm{ve}$ & $-\mathrm{ve}$ \\
Point 9 & $2 \times 10^{4} \pm 1 \times 10^{4}$ & $+\mathrm{ve}$ & $-\mathrm{ve}$ & $3.3 \times 10^{5} \pm 1.8 \times 10^{5}$ & $+\mathrm{ve}$ & $-\mathrm{ve}$ \\
\hline
\end{tabular}

Table (5): Seasonal variations of chemical and bacteriological analysis (Mean \pm SE) of Nile River Fish muscles at Kafr El-Zayat industrial area during 2010.

\begin{tabular}{ccccccc}
\hline Season & \multicolumn{3}{c}{ Spring } & & \multicolumn{3}{c}{ Autumn } \\
Location & Point 1 & Point 3 & Point 9 & Point 1 & Point 3 & Point 9 \\
\hline $\mathrm{Cu}$ & $\mathrm{ND}$ & $\mathrm{ND}$ & $\mathrm{ND}$ & $0.02 \pm 0.008$ & $0.03 \pm 0.001$ & $0.03 \pm 0.005$ \\
$\mathrm{~Pb}$ & $0.02 \pm 0.005$ & $0.02 \pm 0.008$ & $0.08 \pm 0.008$ & $0.06 \pm 0.005$ & $0.04 \pm 0.008$ & $0.25 \pm 0.008$ \\
$\mathrm{Cd}$ & $\mathrm{ND}$ & $\mathrm{ND}$ & $\mathrm{ND}$ & $\mathrm{ND}$ & $\mathrm{ND}$ & $\mathrm{ND}$ \\
$\mathrm{Hg}$ & $4.55 \pm 0.17$ & $9.1 \pm 0.09$ & $4.24 \pm 0.19$ & $1.9 \pm 0.23$ & $1.7 \pm 0.1$ & $2.4 \pm 0.25$ \\
$\mathrm{P}$ & $0.36 \pm 0.022$ & $0.35 \pm 0.01$ & $0.45+0.01$ & $0.36+0.012$ & $0.33+0.002$ & $0.26+0.011$ \\
$\mathrm{NH} 3$ & $17.2 \pm 0.16$ & $19.2 \pm 0.31$ & $16.9 \pm 0.69$ & $24.5 \pm 0.14$ & $27.8 \pm 0.44$ & $26.6 \pm 0.10$ \\
$\mathrm{~S}$ & $46.1 \pm 0.40$ & $43.3 \pm 0.36$ & $40.83 \pm 0.04$ & $30.87 \pm 0.36$ & $34.28 \pm 0.47$ & $32.6 \pm 0.23$ \\
$\mathrm{TBCs}$ & $5 \times 10^{5} \pm 2 \times 10^{5}$ & $4 \times 10^{5} \pm 1 \times 10^{5}$ & $4 \times 10^{5} \pm 2 \times 10^{5}$ & $5 \times 10^{5} \pm 2 \times 10^{5}$ & $3 \times 10^{5} \pm 1 \times 10^{5}$ & $3 \times 10^{5} \pm 1 \times 10^{5}$ \\
Salmonella & $+\mathrm{ve}$ & $+\mathrm{ve}$ & $+\mathrm{ve}$ & $+\mathrm{ve}$ & $+\mathrm{ve}$ & $+\mathrm{ve}$ \\
E. Coli & $-\mathrm{ve}$ & $-\mathrm{ve}$ & $-\mathrm{ve}$ & $-\mathrm{ve}$ & $-\mathrm{ve}$ & $-\mathrm{ve}$ \\
\hline
\end{tabular}




\section{DISCUSSION}

The Nile River has been subjected to different sources of pollution and contamination through several and complicated routes. Industrial effluents constitute a real threat to The Nile River. Recently, the risk of water pollution with toxic chemicals not limited to the public health and veterinary public health only but extended and jointed as toxic chemicals causing zoonotic diseases as reported by El-Tras et al. (2011). The Nile River at Kafr El-Zayat, is impacted by several industrial outfalls from oil and soap, fertilizers pesticides and Sulfur industry (El-Malh and Soda, El-Malyia and El-Mobidat factories). There were other sources of pollution and contamination as agricultural drains, laying carcasses and sewage which discharged from several villages distributed along the two banks of the Rosetta Branch. The present study showed seasonal variation of $\mathrm{pH}$ water values (Table 1 ); the lowest acidic value (6.5) was recorded in spring at point 7 and at point 8 . The highest alkaline value (8.01) was recorded in autumn at point 5 . Presence of carcass pollution at point 7 and the drainage of acids from El-Mobidat company at point 8 may increase the acidity of Nile water. In general the $\mathrm{pH}$ values were always on alkaline side. Massoud and Mahdi (1985) found that the $\mathrm{pH}$ values showed seasonal changes and varied between 7.5 - 8.2. Ahmed (1988) reported that $\mathrm{pH}$ values in water of Nile River at Aswan, Egypt were fluctuated between 7.1 and 8.4. Generally, the $\mathrm{pH}$ values below 6.5 and higher than 9.0 is harmless to fish, although the toxicity of other poisons may be affected by the changes within this range (Alabester and Lioyed, 1980). The mean concentrations of the tested metals in the water of the Nile River at Kafr EL-Zayat in spring followed an abundance of $\mathrm{Hg}>\mathrm{Pb}>\mathrm{Cu}>\mathrm{Cd}$., and in autumn they were in the following order: $\mathrm{Hg}>\mathrm{Cu}>\mathrm{Pb}>\mathrm{Cd}$. In general, the distribution of these metals at the area under investigations are strongly affected by the industrial effluents produced from El-Mobidat, El-Malyia and Salt and Soda companies which directly discharge industrial effluents at this area without any treatment. These results are in a good agreement with that reported by Issa et al, 1996. Seasonal variations of copper in water of Nile River at different selected locations were found to be within the range $0.19-0.30 \mathrm{mg} / \mathrm{l}$ in spring and 0.04 $0.07 \mathrm{mg} / 1$ in autumn (Table 1). According to the Egyptian General Authority of Standardization and Quality Control (2000), the permissible limit of the Copper value in water was $2 \mathrm{mg} / \mathrm{l}$. Therefore, the Nile River at the examined area was not exceeding the permissible limit of Copper in both of spring and autumn. The values of $\mathrm{Pb}$ concentration (Table 1) were found to be in the range of $0.02-0.55 \mathrm{mg} / \mathrm{l}$; the higher values were recorded in spring $(0.18$ - 0.55) and the lower values $(0.02-0.04)$ were recorded in autumn (Table 1). The concentrations of $\mathrm{Pb}$ in the water of the studied area were higher than Egyptian maximum permissible level $(0.01 \mathrm{mg} / \mathrm{l}$.) recommended by Egyptian General Authority of Standardization and Quality Control (2000). Lead pollution could pose a threat to human health such as high pressure, anemia, kidney damage, impaired healing and mental retardation (Wagner, 1995). In addition, the mean values of cadmium concentration (Table 2) were varied in the range of ND $-0.05 \mathrm{mg} / \mathrm{l}$. No cadmium values were recorded at any point in spring; while, in autumn the values ranged between 0.01-0.05 mg/l. These results indicate that cadmium concentration in autumn exceeded the permissible limit $(0.003 \mathrm{mg} / \mathrm{l})$. Cadmium toxicity may cause anemia, dry and scaly skin, emphysema, fatigue, hair loss, heart disease, depressed immune system response, hypertension, joint pain, kidney stones or damage, liver dysfunction or damage, loss of sense of smell, lung 
cancer, pain in the back and legs, and yellow teeth in humans. Additionally, the concentrations of Mercury (Table 2) were found to be in the range of $0.29-0.78 \mathrm{mg} / \mathrm{l}$ in spring; and $0.36-0.60 \mathrm{mg} / \mathrm{l}$ in autumn. Regarding to our results, the pollution with mercury exceeds the permissible limit $(0.001 \mathrm{mg} / \mathrm{l})$ in all examined samples. The presence of high values of heavy metals in this study indicated that the water quality deterioration is pronounced. This result is parallel to Daifullah et al. (2003) and Moustafa et al. (2010) who reported that analyzed water samples at Kafr El- Zayat indicated higher values of $\mathrm{Fe}, \mathrm{Mn}, \mathrm{Zn}, \mathrm{Cu}$, $\mathrm{Pb}, \mathrm{Hg}$ and $\mathrm{Cd}$ than the permissible levels, due to discharges of industrial companies. In general, the distribution of these metals at the area under investigations are strongly affected by the industrial effluents produced from Soda \& Salt and El-Malyia companies which directly discharge industrial effluents at this area without any treatment. These results are in a good agreement with that reported by Issa et al, (1996). In the present study, P concentrations fluctuated between 0.017$0.525 \mathrm{mg} / \mathrm{l}$ in spring; the lowest value was recorded at point 5 , while the highest value was detected at point 8 . In autumn $P$ values were ranged between $0.21-0.40 \mathrm{mg} / 1$ (Table 2). These values may be related to industrial effluents of fertilizers, pesticides, herbicides and detergent enriched by phosphorus. NH3 fluctuated in wide range of seasonal variations and showed high concentrations $(7.2 \mathrm{mg} / \mathrm{l})$ affected by industrial effluents of El-Malyia company discharging into the aquatic environment of the branch at point 3 . The ranges of $\mathrm{NH} 3$ were found to be $0.04-0.37 \mathrm{mg} / \mathrm{lin}$ spring, compared with $2.9-7.2 \mathrm{mg} / 1$ in autumn (Table 3); which showed noticeable increase of NH3 during autumn season. The highest concentration values were recorded during cold season, which may be related to the low water levels and the leaching of fertilizer residues used on the agriculture into the aquatic environment of the branch via drains. This result is coincident with that reported by Abdo (2013) on Rosetta Branch and Abdel-Satar (2008) on Lake Manzalah. Generally, the average values of ammonia concentrations during autumn season in the water of the studied area at Kafr El- Zayat showed higher levels than the chronic guidelines $(1.46 \mathrm{mg} / \mathrm{l})$ recommended by USEPA (1999) for the protection of aquatic life. This result agreed with that finding registered by Abdo (2002), and Abdo (2013) on the same area. The sulpher concentrations were varied in the ranges of $6.78-54.09$ and $5.4-38.11 \mathrm{mg} / \mathrm{l}$ in spring and autumn seasons respectively (Table 3 ). The highest concentration values in both spring (54.09 $\mathrm{mg} / \mathrm{l})$ and autumn (38.11 $\mathrm{mg} / \mathrm{l}$ ) season were recorded at point 4 . The increase in S of Rosetta branch at point 4 could be attributed to the industrial effluents of El-Mobidat Company discharged at these locations. The present results agreed with the findings of AbdelSatar and Elewa (2001), Sayed (2003), Moustafa et al. (2010) and Abdo (2013). The bacteriological examination of water samples from Nile River at Kafr El- Zayat city showed that TBCs ranged from $6 \times 10^{3}$ to $5 \times 10^{5} \mathrm{cfu} / \mathrm{ml}$ and from $1.9 \times 10^{3}$ to $3.7 \times 10^{5} \mathrm{cfu} / \mathrm{ml}$ in spring and autumn, respectively (Table 4). Therefore, there were no significant seasonal changes of Total Bacterial Count in water of Nile River at Kafr EL-Zayat industrial area during spring and autumn 2010. This observation does not comply with previous studies where highest bacterial counts of the River Nile water at Damietta Branch were recorded during summer (Sabae and Rabeh, 2007). The foodborne pathogens that were examined in the present study were: Salmonella spp. and Escherichia coli. The use of these pathogens as indicator bacteria for assessment of faecal pollution and possible water quality deterioration in fresh water sources is widely used (APHA, 1998). Currently, Salmonella spp. and E. coli are of great 
importance among bacterial indicators used in water quality definition and health risk (Giannoulis et al., 2005; McEgan et al., 2013). In the present study, the isolates of genus Salmonella were identified in all points except at points 2, 3 and 4 (Table 4). There were no seasonal changes of Salmonella occurrence in water of Nile River at Kafr EL-Zayat industrial area during spring and autumn 2010. Salmonella spp. previously constituted $11 \%$ of gram-negative bacteria from the examined water samples of Dameitta Branch (Sabae and Rabeh, 2007). Unexpectedly, Escherichia coli were not detected in any water sample in this study. This also indicated that the water of Rosetta Branch at Kafr EL-Zayat is not subjected to sewage pollution or the industrial effluents of water may affect on survival of E. coli. Recently, studies have shown that the combination of ozonated water and metal ions or the dissolution of $\mathrm{ZnO}$ nanoparticles in water may be useful as antimicrobial agents for E. coli (Kang el al., 2013; Li et al., 2013). However, E. coli (as the main indicator of fecal pollution) was detected in $16 \%$ of the identified gram-negative bacteria in the examined water samples of Dameitta Branch (Sabae and Rabeh, 2007). With regards to metal accumulation in tissues of fish, our results indicated that the accumulation of the measured heavy metals increases in the following order:- cadmium $<$ copper $<$ lead $<$ mercury. This interpretation is closely agreed with that reported by Mohamed and Gad, (2008). As shown in Table 5, copper was not detected in fish muscles at any point during spring 2010, and cadmium was not detected during spring or autumn. The seasonal variations were found to be in the range of $0.02-0.03 \mu \mathrm{g} / \mathrm{g}$ in autumn for copper; 0.02- 0.08 in spring and 0.04- 0.25 $\mu \mathrm{g} / \mathrm{g}$ in autumn for lead; $4.24-9.1$ in spring and $1.7-2.4 \mu \mathrm{g} / \mathrm{g}$ in autumn for mercury. The concentration of $\mathrm{Cu}$ in the muscle of the studied fish are below the permissible level for $\mathrm{Cu}(30 \mathrm{mg} / \mathrm{kg})$ recommended by the National Health Medical Research Council (Marks et al, 1980). On contrary, the concentrations of $\mathrm{Pb}$ and $\mathrm{Hg}$ in the muscle of the studied fish were more than maximum permissible level for $\mathrm{Pb}(0.5$ and $0.6 \mu \mathrm{g} / \mathrm{g}$ respectively) recommended by the WHO (WHO, 1986). Therefore, the accumulation of such pollutants in certain tissues of the fishes may cause several hazards or even may be fatal to the consumers. Additionally, seasonal variations of phosphorous in the fish flesh at different selected points were found in the range of $0.35-0.45 \mu \mathrm{g} / \mathrm{g}$ in spring and $0.26-0.36 \mu \mathrm{g} / \mathrm{g}$ in autumn; ammonia 16.9 - $19.2 \mu \mathrm{g} / \mathrm{g}$ in spring and $24.5-27.8 \mu \mathrm{g} / \mathrm{g}$ in autumn; sulphur 40.83 $46.1 \mu \mathrm{g} / \mathrm{g}$ in spring and $30.87-34.28 \mu \mathrm{g} / \mathrm{g}$ in autumn (Table 5). The high values of phosphorus in muscle of Nile fish are in close agreement with values reported by Petenuci et al., (2008). Ammonia is extremely toxic and even relatively low levels pose a threat to fish health (El Gammal and El Shazely, 2008). However, certain fish species can accumulate high levels of ammonia in the brain or defense against ammonia toxicity by enhancing ammonia excretion (Ip and Chew, 2010). The bacteriological examination of fish samples from Nile River at Kafr El- Zayat city showed that TBCs ranged from $4 \times 10^{5}$ to $5 \times 10^{5} \mathrm{cfu} / \mathrm{g}$ in spring and from $3 \times 10^{5}$ to $5 \times 10^{5} \mathrm{cfu} / \mathrm{g}$ in autumn (Table 5). So, no seasonal variation of TBCs in muscle of fish was observed. Similar findings were also noticed in the present study regarding TBC of water samples (Table 4), indicating that $\mathrm{TBC}$ of fish in a certain season is related to the TBC of water in the same season. Importantly, the entire fish samples tested were positive for Salmonella and negative for $E$. Coli. This result is parallel to the results of bacteriological analysis of water samples in this study, proving that the Nile water is the main contamination source for fish in the same area. Egyptian General Authority of Standardization and Quality Control (2000) recommended $10^{6}$ 
total bacterial counts per gram as a maximum permitted limit for fish, and added that fish must be free from Salmonella and Shigella. In addition, Goosney et al. (2001) reported that bacterial pathogens could survive and persist to exploit their host's cellular processes to mediate their effects extracellularly or intracellularly. In a zoonotic survey, Salmonella was isolated from the Nile tilapia fish as the most common pathogen (Onyango et al., 2009). The sources of salmonellae are poorly understood, and this study provides vital data that is critical in assessing and controlling the risk associated with the presence of salmonellae in the Nile environment. The presence of diverse enteric bacteria in the aquaculture environments suggests that strict hygiene procedures should be followed during the handling and processing of fish from the culture systems to prevent the transfer of potentially pathogenic bacteria to humans.

In conclusion, the results demonstrate that the Nile River at Kafr El- Zayat industrial area is heavily polluted and consequently harmful effects to the aquatic environment and to the quality of the water are established. So, pretreatment of different wastes through chemical and microbiological unit before discharging to the River Nile stream is recommended.

\section{REFERENCES}

Abdel-Satar, M.A. 2008. Chemistry of major ions, nutrient salts and heavy metals in Lake Manzalah, Egypt. Egyptian, J. of Aquatic Research, 34(2): $130-148$.

Abdel-Satar, A.M. and Elewa, A.A. 2001. Water quality and environmental assessments of the River Nile at Rosetta branch. The Second International Conference and Exhibition for Life and Environment. Alexandria, Egypt. pp. 136-164.
Abdo, M. H. 2002. Physico- chemical characteristics of Abu zabaal ponds. Egypt J. Aquatic Research 31(2): 1- 15.

Abdo, M.H. 2013. Physico- Chemeical Studies on the Pollutants Effect in the Aquatic Environment of Rosetta Branch River Nile, Egypt Life Science Journal 10(4): 493-501.

Ahmed, M.E.S. 1988. Study of Nile River Water Pollution. M. Sc. Thesis, Fac. Sci. Aswan, Assiut. Univ. Aswan.

Alabaster, J.S. and Lioyed, R.C. 1980. Water quality criteria for freshwater Fish. Food and Agriculture Organization of United Nations. Butter Worth, London, Boston.

APHA. 1998. Standard Methods for the examination of water and wastewater. $20^{\text {th }}$ Ed. Americn Public Health Association Washington, D.C.

Bella, D. A. and Mccauley, J.E. 1972. Environmental considerations for estuarine dredging operations. Proc. World dredging conf. 457. (Cited after Sims and Presley, 1976).

Daifullah, A.A.M.; Elewa, A.A.; Shehat, M.B. and Abdo, M.H. 2003. Evaluation of some heavy metals in water, sediment and fish samples from River Nile (Kafr El-Zyat city), Egypt. A Treatment approach. African J. Environ. Assessment and Management, 6: 16-31.

Elewa, A.A. 1991. Influence of flood water on the physical and chemical features of lake Nubia, Sudan. Bull. Inst. Oceanogra .and fish. 17(1): 97-109.

El Gammal H. A. and El Shazely H. S. 2008. Water quality management scenarios in rosetta river nile branch, Egypt Twelfth International Water Technology Conference, IWTC12 2008 Alexandria, Egypt.

El-Tras W.F., El-Kady N.N. and Tayel A. A. 2011. Infants exposure to aflatoxin M1 as a novel foodborne zoonoses. Food and Chemical Toxicology 49: 2816-2819.

Egyptian General Authority of Standardization and Quality Control 
(EGASQC) 2000. Cairo, Egypt (ES 344 $-2000)$.

Giannoulis, N.; Maipa, V.; Konstantinou, I.; Albanis, T. and Dimoliatis, I. 2005. Microbiological risk assessment of Agios Georgios source supplies in north western Greece based on fecal coliform determination and sanitary inspection survey. Chemosphere 58: 1269-1276.

Gomaa, M. N. E.; Abou Arab, A. A. K.; Badawy, A. and Naguib, K. 1995. Distribution pattern of some heavy metals in Egyptian fish organs. Food Chemistry 53: 385- 389.

Goosney, D.L., Knoechel, D.G. and Finlay, B.B. 2001. Enteropathogenic E. coli, Salmonella, and Shigella: Masters of host cell cytoskeletal exploitation.

Grondelle M.C., Craats Fand Laarse J.D 1977. Microcoulometric determination of total inorganic sulphur in water by a hydroiodic acid reduction method. Analytica Chimica Acta. 92(2): 267275.

ICMSF 1978. Microorganisms in foods. Their significance and methods of enumeration. $2^{\text {nd }}$ Ed., Univ. of Toronto press. Toronto, Canada. International Committee on Microbiological Specification for foods.

I.p, Y.K., and Chew, S.F. 2010. Ammonia production, excretion, toxicity, and defense in fish: a review. Frontiers in Physiology 134: 1-20.

Issa, Y.M.; Elewa, A.A.; Rizk, M.S. and Hassouna, A. F.A. 1996. Distribution of some heavy metals in Qaroun Lake and River Nile, Egypt, Menofiya J. Agric. Res., 21(3): 733- 746,.

Kang, S.N.; Kim, K.J., Park, J.H., Lee, O.H. 2013: Effect of a Combination of Low Level Ozone and Metal Ions on Reducing Escherichia coli O157:H7 and Listeria monocytogenes. Molecules. 4; 18(4): 4018-25.

Li, M.; Lin, D., Zhu, L. 2013. Effects of water chemistry on the dissolution of $\mathrm{ZnO}$ nanoparticles and their toxicity to Escherichia coli. Environ Pollut. 173:
97-102.

Mari'a, C., Garci'a, F., Jose', M., Sidonia, M., Inmaculade, F. and Javier, C. 2007. Microbiological Characteristics of Botillo, a Spanish traditional pork sausage. LWT, 40: 1610-1622.

Marks, P.J., Plaskett, D. Potter, I. and Bradly, J. 1980. Relationship between concentration of heavy metals in muscle tissues and body weight of fish from the Swan-Avon estuaiy, Western Australia. Aust. J. Mar. Fresh. Res. 31: 783-793.

Massoud, S.A.H. and Mahadi, H.A. 1985. Liminological investigation of Rosetta branch of the Nile River (Egypt). I. Environmental conditions. Fresh Water Biology 15(6): 645- 653.

McEgan, R.; Mootian, G.; Goodridge, L. D. Schaffner D. W. and Danyluk M. D. 2013. Redicting Salmonella Populations from Biological, Chemical, and Physical Indicators in Florida Surface Waters. Applied and Environmental Microbiology, 79(13): 4094-4105.

Mohamed F. A. S. and Gad, N. S. 2008. Environmental Pollution-Induced Biochemical Changes in Tissues of Tilapia zillii (Solea vulgaris) and Mugil capito from Lake Qaran, Egypt. Global Veterinaria 2(6): 327-336.

Moustafa, M. M.; Ali M. H.H.; Abdel Satar A., M.; Talat Y. Mohamed1 and Siliem M. Madbouly 2010. Water quality assessment of Rosetta and Damietta Branches, River Nile, Egypt. African J. Biol. Sci. 6(2): 127-142.

National Academy of Science 1985. An evaluation of the role of microbiological for foods and food ingredients. National Academy Press., Washington, D.C.

Nuzzi, R. 1972. Toxicity of mercury to phytoplanketon. Nature 23: 7-238.

Onyango DM, Wandili S, Kakai R, Waindi EN. 2009. Isolation of Salmonella and Shigella from fish harvested from the Winam Gulf of Lake Victoria, Kenya. J Infect Developing Countries 3(2): 99104.

Petenuci, M.E.; Stevanato, F.B.; 
Visentainer, J.E., Matsushita, M., Garcia, E.E., de Souza N.E. and Visentainer, J.V. 2008. Fatty acid concentration, proximate composition, and mineral composition in fishbone flour of Nile Tilapia. Arch Latinoam Nutr. Mar. 58(1): 87-90.

Rabeh, S.A. 2007. Monitoring of microbiological and sanitary quality of water in Rosetta Branch of the Nile River, Egypt. J. Egypt. Acad. Soc. Environ. Develop. 8(4): 57-70.

Ragab, M.K.I. 2001. The effect of water pollution on Hygienic condition of fish. Ph.D. in public Health Science of Food Hygiene and Control Hygiene. Institute Pf Public Health, Alexandria University.

Sabae, S.Z. and Rabeh S.A. 2007. Evaluation of the microbial quality of the river Nile waters at Damietta branch, Egypt. Egyptian Journal of Aquatic Research 33(1): 301-311

Sayed, M.F. 2003. Chemical studies on pollution in Rosetta branch of River
Nile between Kafr El-Zayat and Rosetta outlet. Ph.D. Thesis, Fac. Sci., Cairo Univ. Egypt, pp: 403.

Shewan, J.M. 1971. The Microbiology of fish and fishery products. A progress report. J. Appl. Bacteriol. 34: 299-315.

USEPA, 1999. National recommended water quality criteria-correction-United State Environmental Protection Agency EPA 822-Z-99- 001, pp. 25.

Wheaton, F. W. and Larson. T.B. 1985. Processing of aquatic food product. A Wiley inter science publication, pp. 231-232. Jhon Wiley and Sons, New York, Toronto.

World Health Organization (WHO), 1986. Review of potentially harmful substances-arsenic, mercury and selenium. Reports and Studies, 28: 172.

Wagner, P.D., Evans, S.D., Dunlap, J. and Ballon-Landa, G. 1995. Necrotizing fascitis and septic shock caused by Vibrio cholerae acquired in San Diego, Califoria. West. J. Med., 163(4): 375377. 